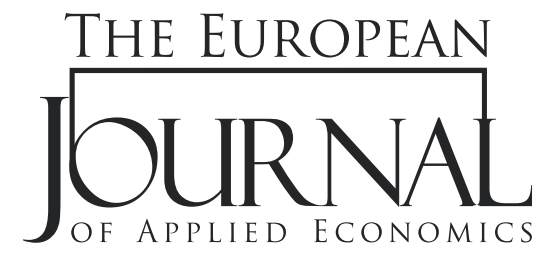

\title{
TOURIST SATISFACTION WITH QUALITY OF SERVICE, FOOD, ATMOSPHERE, AND VALUE FOR MONEY IN RESTAURANTS OF MAJOR CITIES OF THE WESTERN BALKANS
}

\section{Bojan Živadinović*}

Singidunum University,

Belgrade, Serbia

\begin{abstract}
:
An important factor in modern-day tourism is restaurant guests' feeling of satisfaction. Motivated by the desire to quantify this feeling and make it an operational element of recommendations for further development of one segment of restaurant tourism, this paper examines the expressed satisfaction of foreign tourists in restaurants of selected cities in the Western Balkans. The second goal of this paper is to show the extent to which local visitors and domestic tourists are satisfied with the service provided in the analysed catering facilities. Comments that are an integral part of the research part of this paper's analysis were collected from one of the most popular websites in the field of restaurant industry - Trip Advisor.
\end{abstract}

Article info:

Received: July 3, 2020

Correction: July 28, 2020

Accepted: September 8, 2020

\section{Keywords:}

restaurants, foreign tourists, local visitors, Trip Advisor, tourist satisfaction.

\section{INTRODUCTION}

In the digital era of the fourth industrial revolution, tourism is stretching beyond all boundaries and is becoming a global phenomenon. The restaurant industry, being a significant part of the tourism industry, actively follows the newest hospitality trends. The requirements of the increasingly-demanding restaurant customers are being met by listening to the market and continuous introduction of innovations. Mass tourism is losing its dominant position in the overall tourism scope, and the educated tourist of the information age seeks an active vacation. Tourism in cities is recording growth rates, while city restaurants are in growing demand. Restaurants form an integral and significant share of the city's hospitality offer. The topic of this paper is the assessment of the expressed degree of satisfaction of restaurant customers, both local and foreign, in the Western Balkans region, i.e., in the cities that used to be capitals of former socialist Federal Republic of Yugoslavia (SFRY) republics, and are now the capital cities of the newly founded states in the region. As such, they still relate to one another in every sense, including tourism - of which restaurants are a part. 
After arriving to their target destination, tourists satisfy their sustenance needs using the services of these hospitality establishments. Moreover, some guests wish to learn about different cultures by sampling local food specialities (Alderighi, Bianchi, \& Lorenzini, 2016). Restaurants' food, service, and ambience might become some of the more significant magnets for tourists. Whatever the reason for visiting restaurants in the region's major cities, which are subject of this paper's analysis, restaurateurs have an important task ahead of them: to leave as good an impression on their visitors as possible - not only by fulfilling their expectations, but also by striving to surpass them. Noticeably, better-educated modern era tourists do not shy away from sharing their comments about restaurants on social media networks, websites that specialize in specific commentary, etc. The already well-proven importance of oral publicity, which has been the subject of numerous scientific papers, has transformed, and became quite significant as electronic oral publicity (eWOM), too. Social networks have transformed interpersonal relations (Yang, 2020). In the contemporary world, online commentary has reached such a magnitude of popularity that the restaurant choice, its financial state, and the development of new products are decisively dependent on it (Li, Lee, Lee, \& Yang, 2020). This has, however, led to some negative effects too, such as the posting of fake comments that often lead consumers astray (Li, Lee, Lee, \& Yang, 2020). Guests from different countries appraise the same service differently (Radojević, Stanišić, \& Stanić, 2019). Nevertheless, the advantages brought on by the social networks far outweigh their negative effects (Yang, 2020). Posted comments contain information on the level of satisfaction with service processes. Based on the comments written by restaurant customers on the Trip Advisor website, the future restaurant customer assembles as realistic an image as possible of the restaurant that they would potentially visit, deliberates its characteristics and offers, and finally reaches a decision on whether to actually visit it or not. The analysis of these comments is the foundation of this paper, and the conclusions drawn here were based on said analysis. For managers and other interested parties, they may serve as a significant recommendation in undertaking future activities on enhancing restaurant operations.

\section{LITERATURE OVERVIEW}

\section{eWOM and TripAdvisor}

Researchers within the hospitality sector have studied oral publicity for a number of years, and have consistently emphasised its significance. Word-of-mouth (WoM) is a powerful marketing tool, capable of shaping guests' opinions and behaviours. WoM has a tremendous influence on the guest's perception (Nam, Baker, Ahmad, \& Goo, 2020). Oral communication is informal; the direction of its influence is towards other guests, and it describes the characteristics of a particular service or a product (Yen \& Tang, 2019). Digital technologies have led to multiplications of content posted on social media in various forms by hospitality industry customers. These comments, available to everyone, enable potential consumers to read and analyse them. Oral publicity, which is one of a restaurant business's strongest tools, is being replaced in the modern era with electronic oral publicity (eWOM). Electronic oral publicity denotes every negative or positive comment of the current or past customer, which is published publicly on social media and specialised websites and, as such, is accessible by all (Mariani \& Visani, Embedding eWOM into efficiency DEA modelling: An application to the hospitality sector, 2019). Guests have become more sophisticated, and a high level of interactivity is being achieved through new social media (Čačić \& Mašić, 2013). It is of great importance for restaurants that potential customers, by reading reviews regarding their services, believe in the trustworthiness of what is written. 
Tourism businesses should constantly indicate the need for honesty and trustworthiness on social media (Zainal, Harun, \& Lily, 2017). Modern customers use information obtained from social media prior to purchasing, during the service delivery, and after the service delivery itself (Colladon, Guardabascio, \& Rosy, 2019). The so called $e W O M$ is non-commercial information based on customer experience. Electronic publicity has a permanent status, unlike oral publicity where, after the live communication ceases, the communication itself vanishes. Motives related to positive comments are linked to enjoyment and desire to help others, while they can also be influenced by economic benefits (receiving premiums and points for posting positive comments). Motives related to negative comments are based on negative feelings caused by poor hospitality, and the desire to help others not to experience these issues (Hu \& Kim, 2018). The eWOM system helps managers find out what is the maximum price guests are willing to pay for services and products in a restaurant (Nieto-Garcia, Munoz-Gallego, \& Gonzalez-Benito, Tourists' willingness to pay for an accommodation: The effect of eWOM and internal reference price, 2017).

The modern consumer finds information through internet web portals. This information is of great value for both restaurant guests and managers. TripAdvisor is a web portal that chooses the best from the great number of hospitality establishments in its network - by categories, marks and ranks them, and in doing so enables customers to have an overview of a broad spectrum of hospitality establishments sorted by categories (Knežević, Barjaktarević, \& Obradović, 2014). TripAdvisor is the biggest website in the world of tourism, and the number of posted comments is growing each year. TripAdvisor is also becoming more popular by the year (Khorsand, Rafiee, \& Kayvanfar, 2020). The platform has more than 455 million visitors - on average monthly - and 630 million restaurant and hotel views (Giglio, Pantano, Bilotta, \& Melewar, 2019). Essentially, TripAdvisor should help guests utilise the experiences of previous guests who have already used that service, prior to using the service themselves (Nilashi, et al., 2018). Comments posted on TripAdvisor are exceptionally important in the restaurant industry; regular review follow-up, through timely reactions, may improve the restaurant's turnover (Tepavčević, Blešić, \& Bradić, 2018). The credibility of the comments on the network might influence their quality, while in the future the customers will need to separate fake comments from the credible ones (Filieri, Alguezaui, \& McLeay, 2015).

\section{Satisfaction and Attributes of the Restaurant Service}

The quality of restaurant service is the guest's estimation of the service offered in a particular restaurant compared to competitive hospitality establishment. Quality in a restaurant is seen through the tangible and intangible aspects of the service (Han \& Hyun, 2017). Quality in a restaurant is crucial for profitability, and can be both objective and subjective. The objective quality is that which the restaurant owns in the technical sense, while the subjective quality is the way in which a guest perceives that quality (Konuk, 2019). The quality of service, food quality, atmosphere, and value for money are just a few attributes of the restaurant service that impact customer satisfaction. Since the Trip Advisor website, serving as a database for this paper, contains only four of the listed attributes used by restaurant guests to express their satisfaction - they are the subject of the paper research; it would be useful, however, for future papers to research other attributes influencing customer satisfaction, too. Satisfaction is a guest's subjective feeling regarding current and previous experiences in the restaurant (Jeong \& Jang, 2011). 


\section{Restaurant's Atmosphere Quality}

The atmosphere is defined as continued work on the restaurant's design, which should invoke certain emotions in guests that will influence the probability of increased spending. Guests receive these signals through their senses (sight, sound, smell, touch). Employees and management improve the atmosphere through agreeable music, adequate lighting, smells, and colours. The atmosphere is a combination of visual elements with what is audible. Aside from these elements, the atmosphere is particularly impacted by hygiene and odours, as well as the furniture layout and temperature. Research have shown that the tempo of music in a restaurant may affect consumption and length of stay. Psychological research has shown that guest behaviour is linked to the environment: when it comes to restaurants, good food and good service alone are not a guarantee of guest satisfaction. Success in achieving guest satisfaction to a large degree depends on the quality of the environment (Ariffin, Bibon, \& Abdulah, 2012). Colours stimulate restaurant guests and pose a strong visual attraction, thus influencing their perception and behaviour. Guest behaviour may also be influenced by colour shade, its tone and light. For example, romantic dining would require the use of a single colour and dim lighting, while fast-food restaurants have bright lights associated with speed (Tantanetewin \& Inkarojit, 2018). The atmosphere is a factor of satisfaction that influences guest behaviour and impacts consumption. Ambience consists of six elements, namely: aesthetics, illumination, restaurant ambience, restaurant appearance, tableware and employees' appearance (Jeong \& Jang, 2011). Restaurant appearance influences choices and the atmosphere may at times be essential in creating the guests' experience that surpasses their expectations (Basri, Ahmad, Anaur, \& Ismail, 2016). One should point out that the destination allure plays a substantial role in choosing a restaurant. Destination differentiation in times of similar offers is crucial for attracting tourists (Popesku, 2016).

\section{Food Quality}

Food quality can be perceived through a variety of elements, such as: food presentation, diverse menus, the presence of healthy ingredients in meals, the taste of food, freshness, and temperature (Jeong \& Jang, 2011). Cooks are very important for food quality in restaurants. Cooks are leaders; they possess creative abilities, administrative, and technical skills (Peng, Annie, \& Hung, 2017). On the other hand, the appeal of the dish name on the restaurant menu affects its sale. Creatively thought-out names of certain food items can increase their sale by $27 \%$ (Kim, Youn, \& Rao, 2017). Food is linked to a nation's culture, and food quality is central for gastro-tourism. Food represents the culture of the destination, and is a part of the tourism offer (Ellis, Park, Kim, \& Yeoman, 2018). For foreign tourists, food is not just a means for satisfying their essential physiological needs, but a medium for experiencing other cultures. Through food, the hosts convey to the tourists the identity of the destination and bring its lifestyle closer to the guests (Lai, Khoo-Lattimore, \& Ying, 2018). Foreign tourists are only interested in authentic food, made from local ingredients. In addition to home-made food, which is made mostly from local ingredients, there are also national home-made dishes - such as, for example, Leskovac barbecue, and international dishes - such as Viennese steak, Parisian steak, etc. The optimal ratio of meals offered in restaurants is $30 \%$ of home-made food, $30 \%$ of national food while the rest is international food (Kalenjuk, Tešanović, Gagić, Erdelji, \& Banjac, 2015). On the other hand, managers should pay attention to what the restaurant offers, and should constantly introduce innovations in food supply such as, for example, meals containing whole grains, meals with a lower fat content, vegetarian meal options, etc. (Kim, Park, Kim, \& Ryu, 2013). 


\section{Service Quality}

The positioning of hospitality establishments on the market largely depends on the quality of service. In order for tourism companies to be consistently highly positioned, it is necessary to constantly work on raising the quality of services, aiming to satisfy guests (Čerović, 2019). The quality of service is directly related to the satisfaction of employees, who should be motivated to work, since the employee-guest interaction greatly contributes to customer satisfaction (Alhelalat, Habiballah, \& Twaissi, 2017). Professional staff is imperative for every restaurant. A single sommelier in a restaurant greatly multiplies the demand for wine (15-25\%). His/her knowledge of combining food and wine also influences the sale of meals in a restaurant (Gagić, 2016). As mentioned before, an experienced and educated staff is necessary to provide quality service and achieve guest satisfaction. Predicated on quality staff, which will provide high quality service and achieve guest satisfaction, restaurants maintain their competitive position (Kim \& Jang, 2020).

\section{Value for Money}

A lot of attention needs to be paid to pricing in restaurants, because price is a powerful weapon in attracting customers and increasing sales (Yim, Lee, \& Kim, 2014). The period of the Internet development brings changes in the price formation in the hospitality industry; the method differs significantly from the time when information technologies were not represented to this extent. Internet sales are also emerging in the restaurant industry, and new sales channels are being created (Lee, Hallak, \& Sardeshmukh, 2019). The price formation in restaurants is influenced by several factors, one of which is the season (Čerović, Spasić, \& Radović, 2020). During the high season, restaurant prices are higher, while off-season prices are more affordable. Lowering the prices leads to increased revenue, and vice versa (Ubavić, 2012). Price is very often an important indicator of quality and expected satisfaction, because many studies have shown that price can be used to assess quality, mainly since a higher price for a particular product or service indicates higher quality and vice versa (Kiatkawsin \& Han, 2019).

\section{METHODOLOGY}

The research section of this paper is based on the comments of domestic and foreign tourists on the Trip Advisor website, written in regard to service satisfaction in the following cities of the Western Balkans: Belgrade, Zagreb, Sarajevo, Podgorica, Ljubljana and Skopje - capital cities of the former constituent republics of the common state of SFRY which, for a long time, was a common framework for all forms of development, including tourism. There was a total of 3,467 restaurants on the website; out of that number, 614 restaurants had no ratings, i.e., they didn't garner a single comment. Thus, the remaining 2,853 restaurants that garnered reviews by domestic or foreign guests were analysed. A total of 123,298 reviews/comments were gathered from said restaurants.

The main goal of this research is to examine and compare the levels of expressed satisfaction of local and foreign guests in the cities of the region and to investigate the impact of time on this relationship. In order to obtain somewhat more general conclusions about the influence of different examined variables on guest satisfaction, grades (1-5) were divided into two categories: poorly satisfied guests (grades 1, 2 and 3) and satisfied guests (grades 4 and 5). These two categories were used as a dependent variable, which was modelled by the logistic regression method through the influence of a city, type of guest, and the year when the review was written, as independent variables. R statistical programming 
language was used to perform logistic regression (Core Team, R., 2018). Initially, a model was defined that included all mentioned independent variables and their interactions, so elements were gradually excluded from that model, but only if the models obtained in this way were not significantly different from the initial one based on the likelihood-ratio test. When the simplest model was obtained, which according to the likelihood-ratio test does not differ significantly from the initial one, it was used to make multiple comparisons between different categories in order to show which combinations of independent variables significantly differently affect the expressed guest satisfaction.

\section{RESEARCH RESULTS}

In order to perform the category analysis of the written comments according to the user's place of residence, all comments not associated with a particular location were removed before analysis. This resulted in 85,983 unique ratings, which were associated with location and date of the comment. Based on users' place of residence, the comments were divided into two groups: comments by foreign and comments by domestic restaurant visitors.

Graph 1. Number of Restaurants Included in the Study, Per City

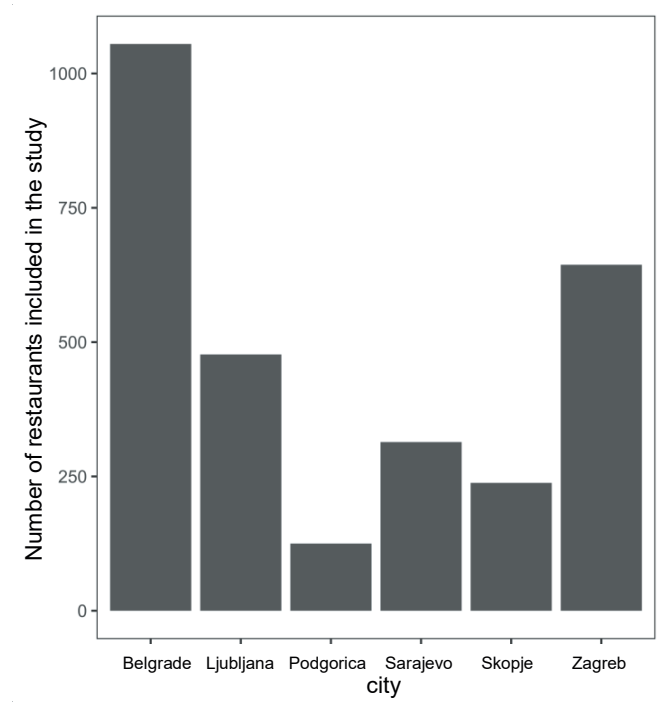

Based on Graph 1, one can notice that Belgrade, with over 1,000 restaurants, is far ahead of other cities in terms of representation on Trip Advisor website, while Podgorica with 125 restaurants, is the least represented. 


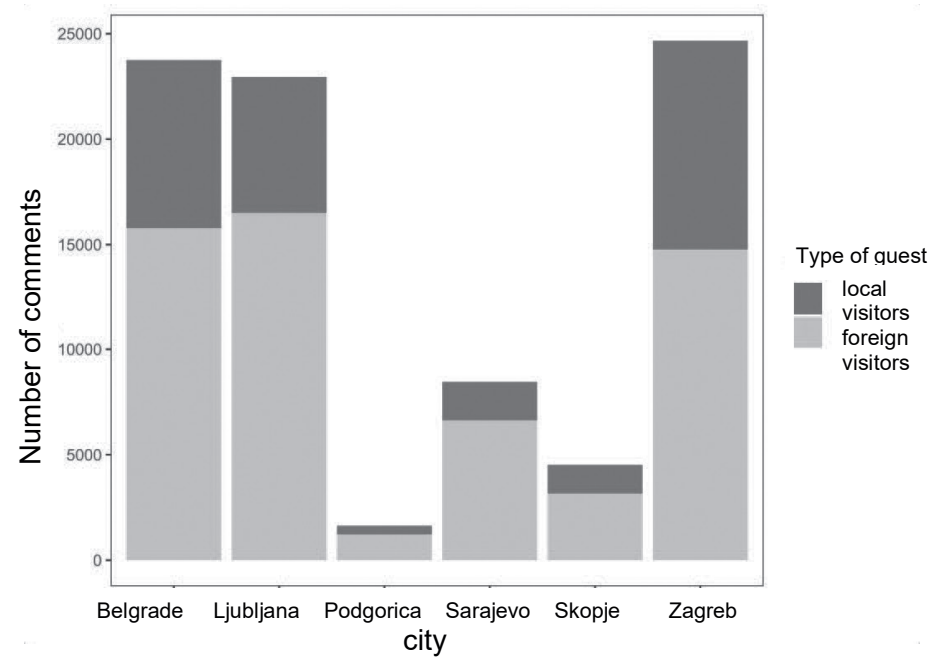

The data from Graph 2 show the total number of ratings on the Trip Advisor website, depending on the city and the type of guest who rated the establishment. Only the ratings with a defined location were summarized. Although Belgrade is the most represented on the Trip Advisor website in terms of the number of restaurants, the number of unique reviews that guests left on the site is fairly equal to Zagreb and Ljubljana (Graph 2). The reason for this is the far greater number of comments per restaurant for these two cities. Thus, e.g., Ljubljana is the only city that has a restaurant with over 1,000 reviews from foreign tourists, while the most rated restaurants in Belgrade have only 500-600 reviews by foreign tourists. Ljubljana and Zagreb are also in the lead in terms of the number of comments from local visitors.

The following graph shows the change in the number of guests' comments by city from year to year:

Graph 3. The Structure of Restaurant Evaluation Frequency in the Region

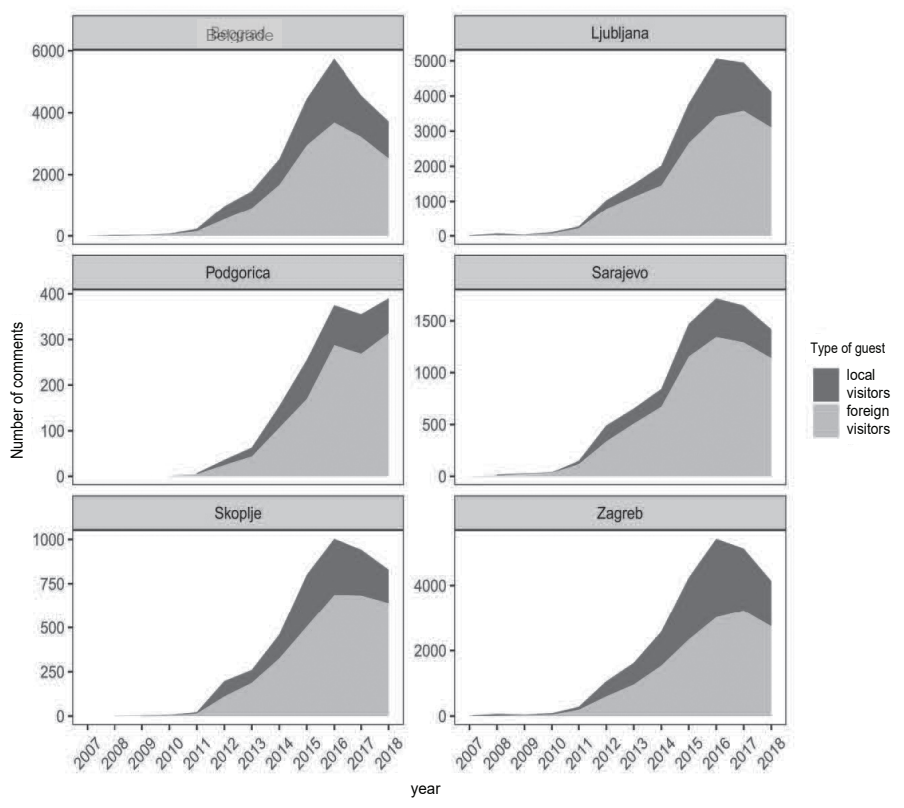


Graph 3 indicates the increase in the number of reviews written by Trip Advisor users over the years, depending on the city and the guest type. Only the ratings with defined location were summarized. The upward trend in the number of comments on the Trip Advisor website (Graph 3) over the years is most likely caused by the growing popularity of the site. One can notice that, prior to 2013 there is a relatively small number of comments, and that the number of written reviews has an exponential growth up to 2016, when it reaches a plateau. Later on, 2018 shows a certain decline, which is probably due to the fact that the collected data did not cover the entire calendar year (data were collected in mid-November 2018). Since guest satisfaction was surveyed on an annual basis, for statistical analysis we considered a five-year period - from 2013 to 2017. The years prior to 2013, were omitted due to a relatively small sample, i.e., a small number of comments for most of the surveyed cities. The year 2018 was omitted because the collected data did not cover the whole year. Therefore, the total number of reviews in the analysis was reduced to 65,989 unique ratings. Based on the data summary (Graph 4), one can conclude that Sarajevo and Belgrade are in the lead in terms of number of the most favourable ratings (5), assigned by both foreign and domestic tourists, while, e.g., Skopje, shows the biggest discrepancy between domestic and foreign tourists' ratings. Local visitors are the most dissatisfied in Ljubljana, while foreign tourists are the most dissatisfied in Skopje.

Graph 4. Percentage Share of Ratings (1-5) by City and Guest Type

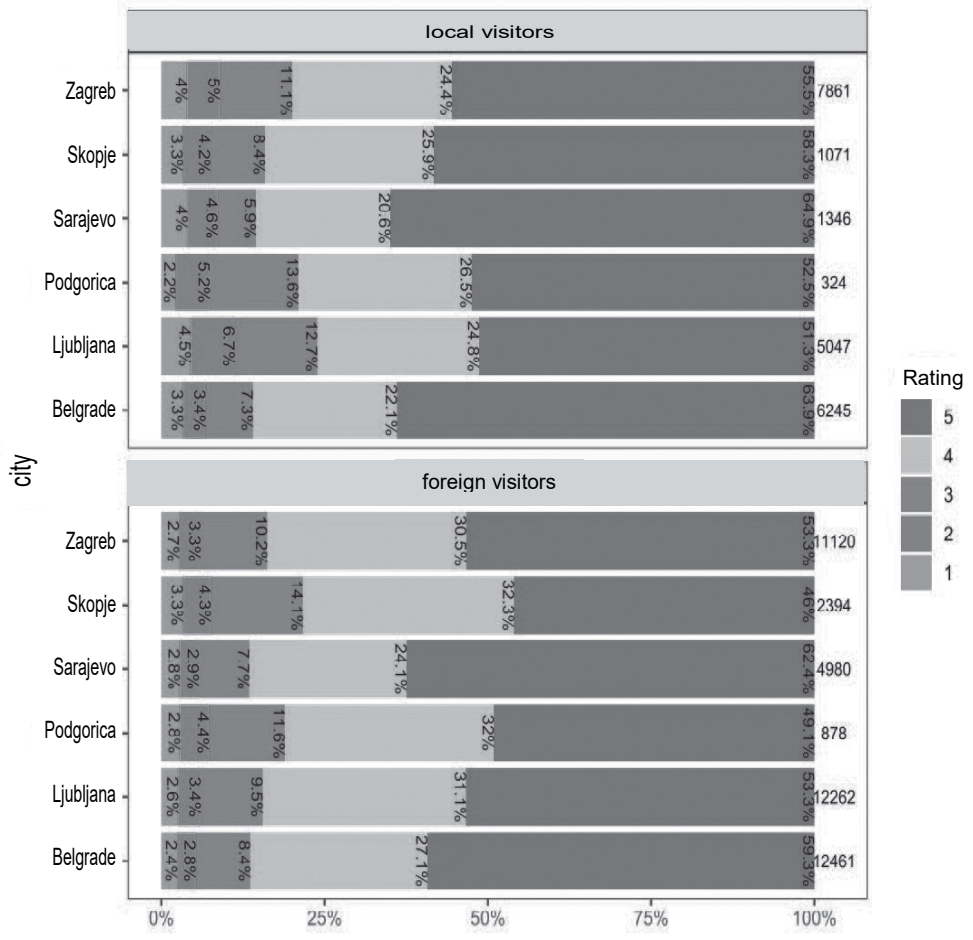

The numbers next to each row indicate the total number of ratings making up the given category combination. Only the ratings for the period 2013-2017 are summarized. 


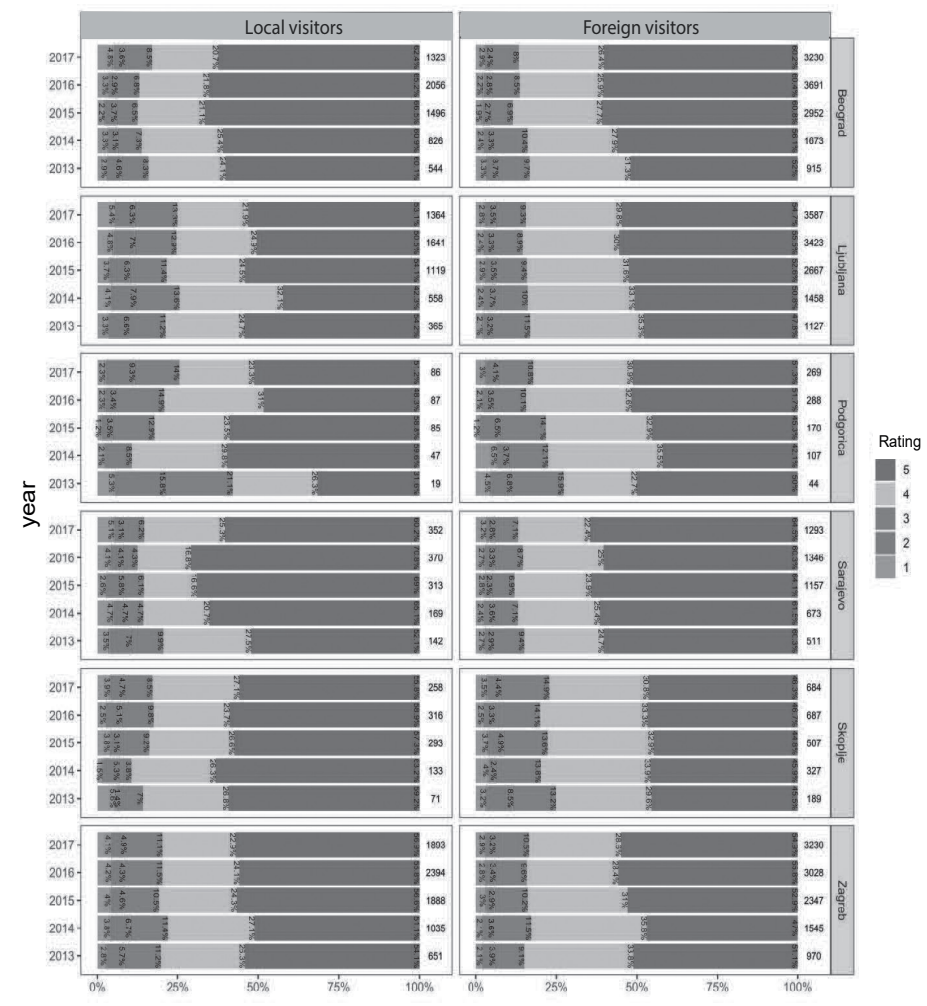

The numbers next to each row indicate the total number of ratings making up the given category combination.

The impact of the year on the ratio of ratings by cities is shown in Graph 5 . The analysis of this graph clearly indicates a high number of negative comments from domestic visitors in 2013 in Podgorica, but this observation should be taken incredulously since it is based on a very small sample (only 19 comments). When you look at the trends of ratings for other cities over time, you can see that the share of the most favourable ratings by foreign visitors increases slightly over the years for all cities except Skopje, which also has the lowest share of the most favourable ratings compared to other analysed ratings. The share of the least favourable ratings ( 1 and 2 ) given by foreign visitors is quite steady over time, and only the example of Podgorica shows a slight downward trend in the share of these ratings over time. The situation is similar with the ratings of local visitors, i.e., these ratings are quite stable over time; only in the case of Podgorica is it possible to notice an extremely large variability over the years, which should, above all, be attributed to the small sample of comments written about restaurants in this city.

In order to examine the influence of various factors on the trends in achieving restaurant guests' satisfaction, logistic regression was used. Since this method models relationships between two classes, guest ratings are summarized into two categories: poorly satisfied (rating 1,2, and 3) and satisfied (rating 4 and 5). A comparison of different models of logistic regression with the likelihood-ratio test showed that the year has no statistically significant impact on expressed guest satisfaction, and that the simplest model, which includes all significant variables, contains city, guest type and city-guest interaction. Thus, the ratio of satisfied and poorly satisfied visitors depends on the city, the type of visitor, and their interaction. In order to gain better insight into the significant variables according to the logistic regression model, the data are summarized in Graph 6, similarly $t$ 


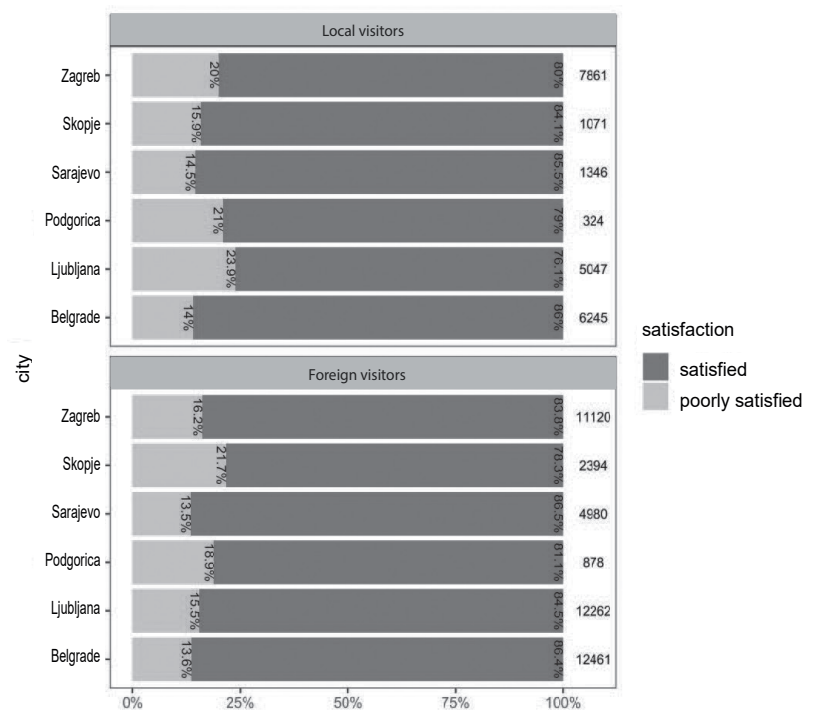

This representation summarizes the data according to significant variables in the logistic regression model.

In order to determine which categories statistically differ significantly, multiple comparisons were conducted based on the logistic regression model between different types of visitors within each city. In addition, the satisfaction of domestic and foreign visitors in all cities was compared with the satisfaction expressed in Belgrade.

Table 1. Multiple Comparisons Between Different Categories Based on the Model Obtained by Logistic Regression

\begin{tabular}{|c|c|c|c|c|c|}
\hline Comparison & $\begin{array}{c}\text { Model } \\
\text { estimate } \\
\text { (Log odds) }\end{array}$ & $\begin{array}{c}95 \% \text { degree } \\
\text { of reliability } \\
\text { (lower) }\end{array}$ & $\begin{array}{c}95 \% \text { degree } \\
\text { of reliability } \\
\text { (higher) }\end{array}$ & p-value & Significance \\
\hline Ljubljana, locals - Belgrade, locals & -0.655 & -0.797 & -0.512 & $<0.001$ & $* * *$ \\
\hline Podgorica, locals - Belgrade, locals & -0.487 & -0.898 & -0.077 & 0.008 & $* * *$ \\
\hline Sarajevo, locals - Belgrade, locals & -0.038 & -0.286 & 0.211 & 1 & \\
\hline Skopje, locals - Belgrade, locals & -0.145 & -0.410 & 0.120 & 0.75 & \\
\hline Zagreb, locals - Belgrade, locals & -0.430 & -0.564 & -0.296 & $<0.001$ & $* * *$ \\
\hline Ljubljana, foreigners - Belgrade, foreigners & -0.154 & -0.258 & -0.049 & $<0.001$ & $* * *$ \\
\hline Podgorica, foreigners - Belgrade, foreigners & -0.391 & -0.653 & -0.130 & $<0.001$ & $* * *$ \\
\hline Sarajevo, foreigners - Belgrade, foreigners & 0.012 & -0.130 & 0.155 & 1 & \\
\hline Skopje, foreigners - Belgrade, foreigners & -0.563 & -0.726 & -0.400 & $<0.001$ & $* * *$ \\
\hline Zagreb, foreigners - Belgrade, foreigners & -0.205 & -0.311 & -0.098 & $<0.001$ & $* * *$ \\
\hline Belgrade, foreigners - Belgrade, locals & 0.034 & -0.096 & 0.165 & 0.998 & \\
\hline Ljubljana, foreigners - Ljubljana, locals & 0.535 & 0.415 & 0.656 & $<0.001$ & $* * *$ \\
\hline Podgorica, foreigners - Podgorica, locals & 0.130 & -0.338 & 0.599 & 0.998 & \\
\hline Sarajevo, foreigners - Sarajevo, locals & 0.084 & -0.171 & 0.340 & 0.99 & \\
\hline Skopje, foreigners - Skopje, locals & -0.383 & -0.666 & -0.101 & 0.001 & $* *$ \\
\hline Zagreb, foreigners - Zagreb, locals & 0.259 & 0.148 & 0.370 & $<0.001$ & $* * *$ \\
\hline
\end{tabular}


Based on the statistical processing of data using logistic regression, several conclusions can be drawn from the table. In terms of local visitors' (residents of Serbia) satisfaction, Belgrade ranks first, relative to other capitals of former Yugoslavia. Local visitors of Belgrade restaurants are significantly more satisfied than local visitors of restaurants in Ljubljana, Podgorica, and Zagreb. Local visitors of restaurants in Skopje and Sarajevo are also satisfied in a similar percentage as local visitors of Belgrade restaurants, and there is no significant difference in the degree of satisfaction expressed. In terms of both local visitors and foreign tourists, Belgrade is in the lead when it comes to guest satisfaction. The only city where the satisfaction of foreign tourists is similar to that of Belgrade is Sarajevo, while in Belgrade foreign tourists are far more satisfied than in Ljubljana, Podgorica, Skopje, and Zagreb. In Belgrade, there is no significant difference between domestic and foreign restaurant visitors when it comes to the satisfaction expressed. Regarding the satisfaction of domestic and foreign visitors, there is no significant difference between the two in restaurants of Sarajevo and Podgorica, unlike Ljubljana and Zagreb - where foreign visitors are far more satisfied than domestic visitors, and Skopje - where domestic visitors are far more satisfied than the foreign. The complete analysis, based on the comments written by Trip Advisor website visitors, showed that Belgrade and Sarajevo are in the lead in terms of satisfaction when it comes to both domestic and foreign restaurant visitors, compared to other capitals of former Yugoslavia.

\section{CONCLUSION}

Relevant literature and presented research have shown that the Trip Advisor website is often visited and used in the restaurant industry, both for reading and for writing reviews (comments) about restaurants around the world. By reading the comments, domestic and foreign visitors create an image and assess the level of satisfaction that a visit to a selected hospitality establishment will potentially provide. By writing personal impressions about the visited restaurants, the guests spread negative or positive publicity/electronic "oral" publicity (eWOM).

The data analysis (reviews from the Trip Advisor website) showed that restaurants in Belgrade and Sarajevo are in the lead in terms of the expressed satisfaction of both domestic and foreign visitors when competing with restaurants in the remaining selected cities. This state of affairs certainly goes to the advantage of Belgrade and Sarajevo and is a positive stimulus to these cities, unlike in Ljubljana, Zagreb, Skopje, and Podgorica, where foreign and domestic restaurant visitors showed less satisfaction.

Such results are of great importance for restaurant managers in cities that were subject to analysis, and often such research and written comments from specialised websites and social networks are guidelines for taking corrective or more aggressive measures in the restaurant business. This one, and similar pieces of research, may be viewed as guidelines to the highest social instances in determining the steps within the government tourism strategies, of which restaurants are an integral part. Future users of restaurant services, assessing the comments for good or bad aspects of them, will be able to see all aspects of satisfaction offered by a potential specific chosen hospitality establishment more correctly. The current state of affairs is in favour of Belgrade (when it comes to comments from the Trip Advisor website), and that is an indicator to the employees in the restaurant industry in the Serbian capital that, according to the results of this research, they are doing a fine job. 


\section{REFERENCES}

Alderighi, M., Bianchi, C., \& Lorenzini, E. (2016). The impact of local food specialities on the decision to (re) visit a tourist destination: Market-expanding or business-stealing? Tourism Management, 57, 323-333. https://doi.org/10.1016/j.tourman.2016.06.016

Alhelalat, J., Habiballah, M., \& Twaissi, N. (2017). The impact of personal and functional aspects of restaurant employee service behaviour on customer satisfaction. International Journal of Hospitality Management, 66, 46-53. https://doi.org/10.1016/j.ijhm.2017.07.001

Ariffin, H. F., Bibon, M. F., \& Abdulah, R. P. (2012). Restaurant's Atmospheric Elements: What the Customer Wants. Procedia - Social and Behavioral Sciences, 38, 380-387. https://doi.org/10.1016/j.sbspro.2012.03.360

Basri, N. A., Ahmad, R., Anaur, F., \& Ismail, K. (2016). Effect of Word of Mouth Communication on Consumer. Precedia-Social and Behavioral Sciences, 222, 324-331. https://doi.org/10.1016/j.sbspro.2016.05.175

Čačić, K., \& Mašić, S. (2013). Uticaj portala TripAdvisor na poslovanje hotela u Srbiji. Marketing, 44(3), 211-220.

Čerović, S. (2019). Upravljanje ljudskim resursima u hotelijerstvu. Beograd: Univerzitet Singidunum.

Čerović, S., Spasić, V., \& Radović, V. (2020). Finansijski menadžment turističko-ugostiteljskih preduzeća. Beograd: Univerzitet Singidunum.

Colladon, F. A., Guardabascio, B., \& Rosy, I. (2019). Using social network and semantic analysis to analyze online travel forums and forecast tourism demand. Decision Support Systems. 123, 113075, https://doi.org/10.1016/j.dss.2019.113075

Ellis, A., Park, E., Kim, S., \& Yeoman, I. (2018). What is food tourism? Tourism Management, 68, $250-263$. https://doi.org/10.1016/j.tourman.2018.03.025

Filieri, R., Alguezaui, S., \& McLeay, F. (2015). Why do travelers trust TripAdvisor? Antecedents of trust towards consumer-generated media and its influence on recommendation adoption and word of mouth. Tourism Management, 51, 174-185. https://doi.org/10.1016/j.tourman.2015.05.007

Gagić, S. (2016). Restaurant Innovativeness: A Case Study of Vojvodina. The European Journal of Applied Economics, 13(2), 57-69. https://doi.org/10.5937/ejae13-10503

Giglio, S., Pantano, E., Bilotta, E., \& Melewar, T. (2019). Branding luxury hotels: Evidence from the analysis of consumers' "big" visual data on TripAdvisor. Journal of Business Research, https://doi.org/10.1016/j. jbusres.2019.10.053

Han, H., \& Hyun, S. S. (2017). Impact of hotel-restaurant image and quality of physical-environment, service, and food on satisfaction and intention. International Journal of Hospitality Management, 63, 82-92. https://doi.org/10.1016/j.ijhm.2017.03.006

Hu, Y., \& Kim, H. J. (2018). Positive and negative eWOM motivations and hotel customers' eWOM behavior: Does personality matter? International Journal of Hospitality Management, 75, 27-37. https://doi.org/10.1016/j.ijhm.2018.03.004

Jeong, E., \& Jang, S. (2011). Restaurant experiences triggering positive electronic word-of-mouth (eWOM) motivations. International Journal of Hospitality Management, 30(2), 356-366. https://doi.org/10.1016/j.ijhm.2010.08.005

Kalenjuk, B., Tešanović, D., Gagić, S., Erdelji, I., \& Banjac, M. (2015). Offer of authentic food as a condition for gastronomic tourism development. The European Journal of Applied Economics, 12(2), 27-34. https://doi:10.5937/ejae12-9139.

Khorsand, R., Rafiee, M. (2020). Insights into TripAdvisor's online reviews: The case of Tehran's hotels. Tourism Management Perspectives, 34,100673. https://doi.org/10.1016/j.tmp.2020.100673

Kiatkawsin, K., \& Han, H. (2019). What drives customers' willingness to pay price premiums for luxury gastronomic experiences at michelin-starred restaurants? International Journal of Hospitality Management, 82, 209-219. https://doi.org/10.1016/j.ijhm.2019.04.024 
Kim, H. J., Park, J., Kim, M.-J., \& Ryu, K. (2013). Does perceived restaurant food healthiness matter? Its influence on value, satisfaction and revisit intentions in restaurant operations in South Korea. International Journal of Hospitality Management, 33, 397-405 https://doi.org/10.1016/j.ijhm.2012.10.010

Kim, H. S., \& Jang, S. (2020). The effect of increasing employee compensation on firm performance: Evidence from the restaurant industry. International Journal of Hospitality Management, 88, 102513. https://doi.org/10.1016/j.ijhm.2020.102513

Kim, J.-H., Youn, H., \& Rao, Y. (2017). Customer responses to food-related attributes in ethnic restaurants. International Journal of Hospitality Management, 129-139. https://doi.org/10.1016/j.ijhm.2016.11.003

Knežević, M., Barjaktarević, D., \& Obradović, P. (2014). Ocenivanje kvaliteta hotelskih usluga putem interneta. U Zborniku radova sa međunarodne naučne konferencije Sinteza 2014 - Uticaj Interneta na poslovanje u Srbiji i svetu (str. 767-771). Beograd: Univerzitet Singidunum. https://doi.org/10.15308/sinteza-2014-767-771

Konuk, F. A. (2019). The influence of perceived food quality, price fairness, perceived value and satisfaction on customers' revisit and word-of-mouth intentions towards organic food restaurants. Journal of Retailing and Consumer Services, 50, 103-110. https://doi.org/10.1016/j.jretconser.2019.05.005

Lai, M. Y., Khoo-Lattimore, C., \& Ying, W. (2018). A perception gap investigation into food and cuisine image attributes for destination branding from the host perspective: The case of Australia. Tourism Management, 69, 579-595. https://doi.org/10.1016/j.tourman.2018.06.033

Lee, C., Hallak, R., \& Sardeshmukh, S. (2019). Creativity and innovation in the restaurant sector: Supply-side processes and barriers to implementation. Tourism Management Perspectives, 31, 54-62. https://doi.org/10.1016/j.tmp.2019.03.011

Li, L., Lee, K. Y., Lee, M., \& Yang, S.-B. (2020). Unveiling the cloak of deviance: Linguistic cues for psychological processes in fake online reviews. International Journal of Hospitality Management,87, 102468. https://doi.org/10.1016/j.ijhm.2020.1024

Mariani, M., \& Visani, F. (2019). Embedding eWOM into efficiency DEA modelling: An application to the hospitality sector. International Journal of Hospitality Management, 80, 1-12. https://doi.org/10.1016/j.ijhm.2019.01.002

Nam, K., Baker, J., Ahmad, N., \& Goo, J. (2020). Determinants of writing positive and negative electronic wordof-mouth: Empirical evidence for two types of expectation confirmation. Decision Support Systems, 129, 113168. https://doi.org/10.1016/j.dss.2019.113168

Nieto-Garcia, M., Munoz-Gallego, P., \& Gonzalez-Benito, O. (2017). Tourists' willingness to pay for an accommodation: The effect of eWOM and internet al reference price. International Journal of Hospitality Management, 62, 67-77. https://doi.org/10.1016/j.ijhm.2016.12.006

Nilashi, M., Ibrahim, O., Yadegaridehkordi, E., Samad, S., Akbari, E., \& Alizadeh, A. (2018). Travelers decision making using online review in social network sites: A case on TripAdvisor. Journal of Computational Science, 28, 168-179. https://doi.org/10.1016/j.jocs.2018.09.006

Peng, N., Annie, C., \& Hung, K.-P. (2017). The effects of teppanyaki restaurant stimuli on diners' emotions and loyalty. International Journal of Hospitality Management, 60, 1-12. https://doi.org/10.1016/j.ijhm.2016.09.010

Popesku, J. (2016). Menadžment turističke destinacije. Beograd: Univerzitet Singidunum.

Radojević, N., Stanišić, N., \& Stanić, N. (2019). The culture of hospitality: From anecdote to evidence. Annals of Tourism Research, 79, 102789. https://doi.org/10.1016/j.annals.2019.102789

Tantanetewin, W., \& Inkarojit, V. (2018). The influence of emotional response to interior color on restaurant entry decision. International Journal of Hospitality Management, 69, 124-131. https://doi.org/10.1016/j.ijhm.2017.09.014

Team, R. C. (2018): A language and environment for statistical computing, R Foundation for Statistical Computing, Vienna (Available at https://www.R-project.org/).

Tepavčević, J., Blešić, I., \& Bradić, M. (2018). Qualitative analysis of guest reviews of Italian restaurants on TripAdvisor. Marketing, 49(2), 83-92. https://doi.org/10.5937/markt802083T 
Ubavić, P. (2012). Characteristics of tourist products and services' prices. 449-464.

Yang, F. (2020). Social media friending in building coworker guanxi: A study in the hotel industry. International Journal of Hospitality Management, 84, 102183. https://doi.org/10.1016/j.ijhm.2018.10.020

Yen, C.-L. A., \& Tang, C.-H. H. (2019). The effects of hotel attribute performance on electronic word-ofmouth (eWOM) behaviors. International Journal of Hospitality Management, 76(A), 9-18. https://doi.org/10.1016/j.ijhm.2018.03.006

Yim, S. E., Lee, S., \& Kim, W. G. (2014). Determinants of a restaurant average meal price: An application of the hedonic pricing model. International Journal of Hospitality Management, 39, 11-20. https://doi.org/10.1016/j.ijhm.2014.01.010

Zainal, N. T., Harun, A., \& Lily, J. (2017). Examining the mediating effect of attitude towards electronic wordsof mouth (eWOM) on the relation between the trust in eWOM source and intention to follow eWOM among Malaysian travellers. Asia Pacific Management Review, 22(1), 35-44.

https://doi.org/10.1016/j.apmrv.2016.10.004 


\section{ZADOVOLJSTVO TURISTA KVALITETOM USLUGE, HRANOM, ATMOSFEROM I ODNOSOM CENA-KVALITET U RESTORANIMA VELIKIH GRADOVA NA ZAPADNOM BALKANU}

\section{Rezime:}

Važan faktor u modernom turizmu je osećaj zadovoljstva gostiju restorana. Motivisan željom da se taj osećaj kvantifikuje i učini operativnim elementom preporuka za dalji razvoj jednog segmenta restoranskog turizma, ovaj rad proučava izraženo zadovoljstvo stranih turista u restoranima odabranih gradova na Zapadnom Balkanu. Drugi cilj je da se pokaže do koje mere su lokalni posetioci i domaći turisti zadovoljni uslugom koja se pruža u analiziranim ugostiteljskim objektima. Komentari koji su sastavni deo istraživačkog dela analize ovog rada prikupljeni su sa jednog od najpopularnijih sajtova iz oblasti restoranske industrije - Trip Advisor.

\section{Ključne reči:}

restorani,

strani turisti,

lokalni posetioci,

Trip Advisor,

zadovoljstvo turista. 